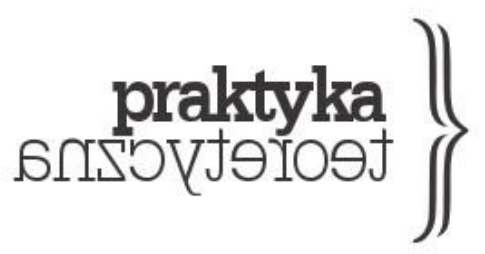

\title{
FÉLIX GUATTARI, KRYTYKA PSYCHOANALIZY I PRZYPADEK LA BORDE
}

\author{
ADRIAN MRÓWKA
}

\begin{abstract}
Abstrakt: Artykuł przedstawia podstawowe założenia teoretyczne Féliksa Guattariego, zawodowo związanego z kliniką La Borde, w której zostały wypracowane nowatorskie metody terapii instytucjonalnej. Krytykując psychoanalizę spod znaku Freuda i Lacana, Guattari stworzył bowiem nietradycyjne narzędzia traktowania tożsamości jednostkowej i zbiorowej, jak również alternatywne sposoby postrzegania produkcji subiektywności oraz fantazmatu grupowego. W klinice La Borde wraz $z$ innymi pracownikami (np. Frantzem Fanonem) rozwinął metody schizoanalityczne oparte m.in. na transwersalnych relacjach i maszynowej nieświadomości, czyli terminach ściśle powiązanych z teoretycznymi i filozoficznymi założeniami Anty-Edypa.
\end{abstract}

Słowa kluczowe: Félix Guattari, La Borde, krytyka psychoanalizy, podmiotowość, schizoanaliza. 
Gilles Deleuze w króciutkim tekście zatytułowanym Dla Féliksa, napisanym po śmierci Guattariego, podjął próbę ogólnego opisu dorobku swojego naukowego przyjaciela. Zajęły go, co ważne, nie te prace, które napisali wspólnie, lecz te, które wyszły spod pióra samego Guattariego. Za domenę, której Guattari najwierniej się poświęcił, bezsprzecznie Deleuze uznał psychiatrię. Z punktu widzenia instytucjonalnej analizy Guattari wprowadził bowiem dwie istotne koncepcje: „podmioty zbiorowe” oraz „niehierarchiczne” i ,transwersalne relacje”. Charakter obu tych koncepcji, zdaniem Deleuze'a, jest w takim samym stopniu psychiatryczny, co i polityczny. Wspólnego ich mianownika natomiast filozof doszukał się w problemie szaleństwa. Szaleństwa, które jest - po pierwsze - patologicznym procesem podlegającym leczeniu, po drugie - obiektem zainteresowania politycznie sterowanej opieki medycznej (Deleuze 2006, 382). Nigdy jednym bez drugiego.

Marzeniem Guattariego było utworzenie systemu, który mógłby uwolnić się spod jarzma tradycyjnej psychoanalizy podporządkowanej układowi „matka-ojciec” czy rasie i nawiązać kontakt z tym, co „rzeczywiste”. W tym celu Guattari w swoich badaniach wykorzystywał cztery aspekty terapeutyczne: sektory nauki, filozoficzne koncepcje, życiowe doświadczenie oraz sztukę (artystyczne kreacje). Takie podejście okazało się owocne. Z biegiem czasu pozwoliło mu na wypracowanie systemu terapii, który sprawdzał się dzięki współpracy z pacjentami w dużym stopniu różniącymi się między sobą (Deleuze 2006, 382).

Klinika La Borde, oddalona o godzinę drogi od Paryża na południe, została założona w 1953 roku przez Jeana Oury’ego, psychiatrę i psychoanalityka wywodzącego się z paryskiego środowiska skupionego wokół postaci Jacques’a Lacana. Obszarem zainteresowania kliniki była nie tylko psychiatria, ale i pedagogika. Oddziałem instytucjonalnej pedagogiki kierował brat Jeana Oury'ego - Ferdynand Oury. Guattari do La Borde trafił w 1955 roku wskutek prośby Jeana Oury'ego. Pomimo iż zasoby materialne kliniki były niewielkie, to wolność działania, jaką ona oferowała - jak wspomina Guattari- była fascynująca (Guattari 2009, 176).

W 1955 roku Guattari prowadził zaawansowanie badania nad psychozami. Zakres jego zainteresowań w tym okresie był zbieżny z kierunkiem terapii, który obrała La Borde. „Psychoza może pokazać - twierdził psychoanalityk - swoją prawdziwą twarz tylko w kolektywnym życiu rozwiniętym w obrębie odpowiednich instytucji, twarz, która nie jest z pewnością obca bądź zła [a face that's certainly not one of strangeness or violence], nie jest ta, w którą wszyscy często wierzą, lecz tą, która wskazuje na inną relację z rzeczywistością" (Guattari 2009, 176). I ta „inna relacja z rzeczywistościa” - jako zagadnienie - stała się zasadnicza. Pozwoliła bowiem Guattariemu wsiąknąć w realia La Borde i nie opuścić ich aż do śmierci. 
Naszym celem - mówił Guattari w wywiadzie udzielonym w 1972 roku, wspominając La Borde - było teoretyczne i praktyczne zdefiniowanie podstaw psychoterapii instytucjonalnej (ja pracowałem nad takimi pojęciami jak „transwersalność" i „fantazmat grupowy”) (Deleuze 2007, 27).

Klinika La Borde wszczęła minirewolucję. Zaproponowano tam, by personel niemedyczny udzielał się w obowiązkach medycznych oraz by pracownicy medyczni zajęli się sprzątaniem, gotowaniem, utrzymywaniem ośrodka czy ogrodu. O rotacji poszczególnych stanowisk decydował grafik. Po kilku miesiącach funkcjonowania klinika zmieniła charakter swojej działalności. Lęk pokojówek i księgowych przed podawaniem zastrzyków ostatecznie zaniknął. Niektórzy pracownicy odkryli swoje nowe talenty. Guattari wspomina między innymi przypadek praczki, która wielokrotnie udowodniła swoją kompetencję w zakresie tworzenia gazety lub przypadek metalurga, który wykazał się dużymi zdolnościami pantomimicznymi (Guattari 2009, 178). Jak się okazało, wprowadzenie grafiku decydującego o okresowych zmianach profesji umożliwiło odrzucenie prawa seryjności opartego na tym, co powtarzalne, a także zakwestionowanie szablonowej oraz biernej praktyki (Guattari 2009, 178). Było ono wymierzone w skostniały podział obowiązków i - tym samym - w rutynę codzienności. Klinika w efekcie utworzyła około czterdziestu różnych stanowisk dla jej mieszkańców (stu pacjentów i siedemdziesięciorga pracowników), a także dwadzieścia sektorów badań, które podważyły tradycyjną analizę nieświadomości. Z kolei za główny cel działalności w klinice obrano tzw. instytucjonalną produkcję subiektywności.

Ustalmy podstawowe założenia myśli Guattariego. Subiektywność, wedle jego postulatów, powstaje w wyniku procesu „maszynowego”. Proces ten sprzyja „bardziej kreatywnemu" rozwojowi jednostki, sprzeciwiając się redukcji jej libido do założeń strukturalistycznych czy do analizy czysto symbolicznej. Guattari mówił:

\begin{abstract}
„Wytwarzanie” podmiotu przebiega obecnie przez długi i skomplikowany proces włączający rodzinę, szkołę, „maszynowe” systemy (jak telewizja, różne media, sporty itp.). Muszę domagać się [uznania] faktu, iż nie jest to [tj. wytwarzanie podmiotu przyp. AM] wyłącznie kognitywna treść subiektywności [cognitive content of subjectivity], która poddaje się procesowi modelowania [modelization], lecz również jest to każdy inny aspekt: afektywny, percepcyjny, wolicjonalny, mnemoniczny... (Guattari 2009, 182-183).
\end{abstract}

Wypracowując własne stanowisko, Guattari ostatecznie odwrócił się od Lacana. Inspiracji dostarczali mu tacy przedstawiciele antypsychiatrii jak Franco Basaglia, Ronald David Laing 
i David Cooper. Psychoanaliza Lacana - diagnozował - jest pretensjonalna w swoim utrzymywaniu założenia, że tylko indywidualne leczenie, poprzez tajemne, transcendentne drogi interpretacji, pozwala jednostce wkroczyć w obręb porządku symbolicznego. „Psychika, w gruncie rzeczy, jest wypadkową wielorakich oraz różnorodnych elementów. Z całą pewnością włącza rejestr języka, lecz również niewerbalne środki komunikacji” (Guattari 2009, 191) - twierdził. Rzecz w tym, że lacanizm nie jest ponownym odczytaniem Freuda, jest o wiele bardziej despotyczny i sztywny w swej teorii i instytucjonalności. „Freudyzm był obronny w swoim nastawieniu do medycyny, psychiatrii, akademickiego świata. Lacanizm, przeciwnie, atakuje, jest walczącą teoria”" (Guattari 1984, 49-50). Wprowadzenie matematyczno-lingwistycznego systemu badania nieświadomości „skłania zasadniczo, by oddzielić pożądanie od rzeczywistości” (Guattari 1984, 50). System ów, czyniący z psychoanalityków zamkniętą kastę, kierującą pożądaniem pacjenta w sposób, który upraszcza jego reprezentację, narzucając mu reprodukcję mieszczańskiej subiektywności. Operowanie wzniesioną na binaryzmie techniką interpretacji nie prowadzi w związku z tym do niczego innego, jak tylko do uproszczeń i pominięć: do bezpowrotnej utraty niektórych form życia, aż w końcu - jak mówi zbuntowany uczeń Lacana - do efektu „czarnej dziury” (Guattari 1984, 70).

Nieświadomość jest „kłączem maszynowych interakcji, związkiem mocy systemów i sił relacji, która nas otaczają" (Guattari 2009, 202). Nie jest ona własnością specjalistów. Każdy, bez względu na wykonywany zawód, ma do niej dostęp. Tak ujmowaną nieświadomość Guattari zwie schizoanalityczna. Nieświadomość schizoanalityczna jest inspirowana psychoza, a nie, co ma miejsce w przypadku psychoanalizy, nerwica. To ważna uwaga z punktu widzenia historii badań nad nieświadomościa.

Zdaniem Guattariego stare obszary Ego, rodziny, zawodu, religii, etniczności itp. mogą zostać „rozpięte” i poddane deterytorializacji. Zadaniem nowoczesnej analizy nieświadomości powinno być promowanie różnych jej wariantów. Freud, na przykład, postrzegał nieświadomość jako „wewnętrzny” program, który podporządkowany jest ogólnemu przeznaczeniu. Schizoanaliza odbiega od tego typu uniwersalizmów. Tu nieświadomość jest już polem interakcji pomiędzy semiotycznymi składnikami a różnymi systemami (w tym miejscu można wymienić: semiotykę językową, semiotykę etologiczna, semiotykę ekonomiczną itd.). Dlatego też, jak argumentuje Guattari, nieświadomość nie odpowiada aksjomatowi sformułowanemu przez Lacana, założeniu, według którego jesteśmy skonstruowani jak język. Nieświadomość nie jest także podporządkowana uniwersalnej składni. Przeciwnie, podlega procesom jednostkowości: procesom niepowtarzalności. „Maszynowa nieświadomość jest niczym sklepowy dział - można w niej znaleźć, co tylko się chce. To wyjaśnia jej uległość wobec konsumpcyjnego społeczeństwa, jej bogatą kreatywność i otwarcie się na innowację" (Guattari 2009, 199-200). Nieświadomość 
rozwija się wraz z historia. Może ona również odmykać się na przyszłość. Wobec tego klasycznie prowadzone leczenie uwikłane w archaiczne fiksacje, jak na przykład narcyzm, popęd śmierci, strach przed kastracją powinno - w opinii Guattariego -podlegać starannej rewizji (Guattari 2009, 200).

Schizoanaliza likwiduje sztywne opozycje, znosi podział na "Ja” oraz „Innego”. Zakłada, że kategorie takie jak np. mężczyzna i kobieta, rodzic i dziecko nie wykluczają się wzajemnie (czego chciał chociażby Freud), lecz równocześnie egzystują w polu pojedynczej podmiotowości. Nie są one konkretnymi istnieniami, jednostkami spolaryzowanymi, są za to intensywnościami, które umożliwiają wejście do wszechświata nieustannych transformacji. Podmiotowość schizoanalityczna nie podlega właściwej dla tradycyjnej psychoanalizy opozycji: „rzeczywistość-reprezentacja” (Guattari 2009, 201). Podjęcie tematu podmiotowości schizoanalitycznej sprawia, że pojęcie „reprezentacji” traci wszakże na znaczeniu.

Kategoria intensywności zakłada odrzucenie uniwersalnych „zamkniętych” figur na rzecz perspektywy, która uznaje pierwszeństwo urozmaiconych oraz w różnym stopniu natężonych sił i przepływów. W Anty-Edypie czytamy, że schizoanaliza nie respektuje prawa występowania monolitycznej (esencjalistycznej) płciowości człowieka - tylko męskiej czy wyłącznie kobiecej - zwraca się natomiast ku różnym elementom (również tym nieludzkim, tj. zwierzęcym, roślinnym), które pełnią funkcje budulców nieświadomości pracującej wedle reguł „rozpraszania” (przykład orchidei i osy, na który powołują się Deleuze i Guattari [Deleuze i Guattari 2000, 323]). Rozpraszanie (dispersion) neguje istnienie granic nie do zniesienia. Rozpraszanie, innymi słowy, konstytuuje sposób obecności w mnogości, to jest anarchiczną wielość ${ }^{1}$. Unieważnia egzystowanie podmiotu pod postacia Ja, by w zamian tego wspierać formę życia, która wyraża się poprzez nomadyczne połączenia oraz mikroskopijną transseksualność: zawsze-aktualne-my. Jak zaznaczają Deleuze i Guattari: „Schizoanaliza jest zmiennym badaniem n-tej liczby płci w podmiocie" (Deleuze i Guattari 2000, 296). Oznacza to, że odsyła ona do afirmacji bycia kobietą, która zawiera w sobie taką samą liczbę mężczyzn, co dowolnie wskazany mężczyzna, bądź też - dla odmiany - do afirmacji bycia mężczyzna, który jest jednocześnie wieloma kobietami. Albowiem wszyscy - jak głosi teoria schizoanalityczna - są w stanie podlegać takim regułom produkcji pożądania, które wywracaja tradycyjny porządek obu płci i ich politycznie determinowanych reprezentacji (innymi słowy - genderów).

Franco Berardi - uczeń i przyjaciel Guattariego - wyjaśnia:

\footnotetext{
1 „Rozpraszanie” odnosi się do organów lub ich fragmentów, obiektów, które zwracają się ku mnogościom życia, nie odsyłając do organizmu jako pewnej utraconej jedności. Rozpraszanie organów nie ma nic wspólnego - w psychoanalitycznym sensie - z tzw. brakiem, który byłby źródłem pożądania (Deleuze i Guattari 2000, 324).
} 
Schizoanaliza nie jest tylko metodą psychoterapeutyczna, lecz także sposobem tworzenia związku pomiędzy pojedynczością [singularity] a jej chaosmosis, czyli jej pojęciowymi, artystycznymi, psychicznymi, egzystencjalnymi, politycznymi, relacyjnymi oraz językowymi kreacjami - kreacjami, które konstytuują świat jako szczególną płaszczyznę, na której możliwe jest podążanie w stronę spotkania $\mathrm{z}$ innymi pojedynczościami (Berardi 2008, 113-114).

Schizoanaliza buduje pomost pomiędzy Ja a światem, mówi o samym stawaniu-się-światem. Zakłada, że ekologia umysłu odpowiada ekologii świata. W schizoanalizie stawanie- sięświatem możliwe jest za pomoca otwarcia nieświadomości na świat. Na inne.

Berardi tłumaczy, że koncepcja schizoanalizy „,należy do procesu filozoficznej mutacji, która rozprasza stałe myślenie i wprowadza myślenie płynne jako szeroko rozpowszechniona modalność rozumienia" (Berardi 2008, 114). Dzięki schizoanalizie możliwa staje się nieustanna modyfikacja różnych form życia, jak i produkowanie nowych jakości istnień. Dzięki schizoanalizie również następuje zerwanie z „refrenem”, który - zgodnie z prawem powtórzenia - nadaje jednostce tożsamość (który wprowadza ją w tożsamość - w język, w kody kultury, które „przypominaja” jej o tym, kim jest). Rzecz bowiem w tym, że to, co tożsamościowe, musi być „utwardzane” przez powroty jednostki do rytuałów. Dzięki powracaniu do tego, co kryje się pod pojęciem Ja, jednostka wpisuje się w tradycję, kulturę, historię. Na drodze cyklicznych powrotów staje się kimś, kto „pilnuje” swojej reprezentacji i - zarazem - kto „strzeże” swojego miejsca w świecie. Berardi pisze:

\footnotetext{
Refren jest obsesyjnym rytuałem wprowadzanym w językowym, seksualnym, społecznym, produktywnym, egzystencjalnym zachowaniu, by pozwolić jednostce świadomemu organizmowi w ciagłych wahaniach - odnaleźć identyfikację [identification points], to znaczy, by mogła ona terytorializować siebie i przedstawiać siebie w relacji do świata, który ją otacza (Berardi 2008, 129).
}

Odrzucenie refrenu jest odrzuceniem kultury. Jednostka odrzucająca refren, który bierze ją w „posiadanie”, wkracza w rejony czystej subiektywności, niejęzykowych wymiarów życia (takich jak bełkot, chichot, jąkanie się etc.). Innymi słowy, zwraca się w stronę nieświadomości. Nie postrzega się w kontekście swojego miejsca-w-świecie (opozycji Jaświat, która ją określa), lecz sama rozpoczyna stawanie-się-światem - w sensie afirmatywnym. Tradycyjna psychoanaliza widzi nieświadomość jako niebezpieczną. Libido w ujęciu psychoanalitycznym musi podporządkowywać się powszechnie akceptowanym wartościom, 
stąd wymaga ono specjalnego nadzoru. Samo zaś zostaje naznaczone negatywnością, brakiem. Stanowisko Guattariego jest zdecydowanie przeciwne. „Nieświadomość - jak konstatuje jest w pełni pozytywna” (Guattari 1984, 70), dlatego też należy pozwolić jej na swobodną produkcję i - tym samym - nie limitować jej. „Osoba uwięziona w dwubiegunowych systemach, jak: mężczyzna/kobieta, dziecko/dorosły, genitalne/pregenitalne, życie/śmierć itp., stała się już podmiotem na drodze zmierzania do reprezentacji podlegającej redukcji pożądania za pomocą aktu edypalizacji”" (Guattari 1984, 72).

Deleuze na przykład powie:

Idealizm psychoanalizy oznacza dla nas cały system poskramiania i redukcji zarówno w teorii, jak i w praktyce analitycznej: redukcji produktywności pragnienia do pewnego systemu przedstawień zwanych nieświadomymi i do odpowiadających im form przyczynowości, ekspresji oraz rozumienia; redukcji fabryk nieświadomego do sceny teatralnej, do Edypa, Hamleta; redukcji społecznych inwestycji libido do inwestycji rodzinnych, przypisanie pragnienia do płaszczyzny rodzinnej - Edyp raz jeszcze (Deleuze 2007, 29).

Guattari ratunku poszukuje w sile grupowej, samym libido, w zwróceniu się ku społecznej przestrzeni i w zerwaniu ze znaczącym (signifiant).

Zlikwidowanie nieświadomej subiektywności instytucji (niebezpiecznej - powiedziałby Guattari) staje się możliwe dzięki wprowadzeniu transwersalnego układu, a więc, w gruncie rzeczy, antyukładu. Transwersalność sprzeciwia się dwóm porządkom: wertykalnemu piramidalnej strukturze, podziałowi instytucji na kierowników, liderów, asystentów itd., a także horyzontalnemu - idei oddziału szpitalnego, który miałby być przeznaczony tylko dla chorych umysłowo czy też dla osób w starszym wieku (Guattari 1984, 17). Transwersalność pozwala tym samym na rezygnację z prawa znaczącego, umożliwiając pacjentowi dostęp do „każdej” roli. Transwersalność wyrzeka się podziału na pana i niewolnika, pokonując w ten sposób kompleks kastracji (Guattari 1984, 22). Guattari tłumaczył: „Transwersalność jest wartościa, która próbuje pokonać impas czystej wertykalności oraz czystej horyzontalności: zmierza ona do maksymalnej łączności na różnych poziomach i, nade wszystko, w różnych znaczeniach” (Guattari 1984, 18). Grupa nie jest przedmiotem, jest podmiotem. Koncepcja transwersalności obala ideę struktury rodziny, organizacje pracy w społeczeństwach kapitalistycznych, instytucjach hierarchicznych - kościele, uniwersytecie, wojsku. Grupa jako podmiot nie jest bowiem sumą jednostek. 
Nie produkuje pojęć, tworzy natomiast znaczące - lecz nie znaczenia. Grupa-podmiot wytwarza tymczasową prawdę, jedną spośród tych, które mogą się urzeczywistnić (Guattari $1984,18)$.

Uniwersalne matematyczno-graficzne oznakowania Wyobrażonego, Symbolicznego, Realnego (Lacan) uprzedmiotawiają wielorakości. Guattariego nie interesują ogólniki, lecz rzeczywiste oblicza życia, a te, jak argumentuje, wynikają z „każdego dnia, snu, namiętności, szaleństwa, depresji bądź estetycznego doświadczenia” (Guattari 2011, 18). Każde z tych oblicz różni się swym ontologicznym ubarwieniem, a próba sprowadzania ich do jakiegoś jednego uniwersalnego poziomu, do tzw. korzenia świata, nie jest niczym innym jak tylko ich maltretowaniem. Stąd wynika też propozycja Guattariego na wskroś, jak może się wydawać, radykalna, którą da się zawęzić do stwierdzenia: porządek/porządki zastapmy chaosem. Chaos w terminologii Guattariego ma jednak wyjatkowe znaczenie. Nie jest on niezróżnicowany. Posiada specyficzny układ nici, przypominający tkaninę, splot wątków. Nie ma początku ani końca, ani centrum, ani marginesów. Obejmuje rzeczywiste byty i alternatywy inności, które nie zawieraja w sobie żadnych uniwersalnych składników (Guattari 2011, 20). Guattari mówi: chaos połączmy z pojęciem osmozy - otrzymamy chaosmosis. Zwrócenie się ku chaosowi i - w związku z tym - ku schizoanalizie daje szanse procesowi leczenia na wyswobodzenie się z „odgórnie” ustalonych znaczących (signifiants), na dekonstrukcję narzuconych mu celów (Guattari 2011, 23-24). Ja jest tutaj innym, wielością innych. Ja jest uosobieniem przecięcia się różnych elementów, które naruszają na wszystkie możliwe sposoby zindywidualizowaną tożsamość oraz zorganizowane ciało (Guattari 1995, 83). Stąd Ja nie może być traktowane jako figura homogeniczna i stała, lecz - przeciwnie jako figura wciąż rozwijająca się, heterogeniczna, a-centryczna, jednym słowem: rizomatyczna.

Wróćmy do La Borde, której profil jest przełożeniem Guattariańskiej teorii chaosu na praktykę instytucjonalną. Wspierając jednostkową subiektywność, zarówno pacjenta, jak i pracownika, klinika La Borde nie odgradza ani pierwszego, ani drugiego od grupowej produkcji subiektywności. La Borde wspiera rekonfiguracje ciała, Ego, przestrzeni życia, relacji z innymi. Angażuje cały personel do każdego instytucjonalnego aspektu funkcjonowania. Aż w końcu nie traktuje „oryginalności” jako „zniekształconej” uniwersalności; przeciwnie - dąży do wspomagania jej rozwoju w jednostkowej oraz zbiorowej praktyce (Guattari 2009, 193-194). 
Doświadczenie zdobyte w La Borde pokazało, że eklektyzm opisów różnych jednostek chorobowych oraz regularne spotkania grupowe sa w stanie utworzyć pozytywne zwroty terapeutyczne. La Borde, odrzucając segregację ze względu na wiek, typ choroby, rasę², płeć, zawód, wykształcenie, religię, ekonomię wypracowała nową - zapewne nie można stwierdzić, że doskonała, aczkolwiek wartą uwagi - jakość terapii.

2 Warto dodać, że jednym z lekarzy psychiatrów pracujących w La Borde był Frantz Fanon, autor m.in. głośnej książki Black Skin, White Masks, teoretyk kolonizacji i działacz polityczny. 


\section{Wykaz literatury}

Berardi, Franco. 2008. Félix Guattari: Thought, Friendship and Visionary Cartography. Red., tłum. G. Mecchia, C. J. Stivale. London: Palgrave Macmillan.

Deleuze, Gilles. 2006. „For Félix”. Tłum. A. Hodges, M. Taormina. W Gilles Deleuze. Two Regimes of Madness. Texts and Interviews 1975-1995. Red. D. Lapoujade. New York: Semiotext(E).

Deleuze, Gilles. 2007. „Rozmowa o »L'Anti-CEdipe« (wspólnie z Feliksem Guattarim)”.

Tłum. M. Herer. W Gilles Deleuze. Negocjacje 1972-1990. Wrocław: Wydawnictwo Naukowe Dolnośląskiej Szkoły Wyższej Edukacji TWP we Wrocławiu.

Deleuze, Gilles i Félix Guattari. 2000. Anti-Oedipus. Tłum. R. Hurley, M. Seem, H. R. Lane. Minneapolis: University of Minnesota Press.

Guattari, Félix. 1995. Chaosmosis. An Ethico-Aesthetic Paradigm. Tłum. P. Bains, J. Pefanis. Bloomington, Indianapolis: Indiana University Press.

Guattati, Félix. 2009. Chaosophy. Texts and Interviews 1972-1977. Red. S. Lotringer. Tłum. D. L. Street, J. Becker, T. Adkins. Los Angeles: Semiotext(E).

Guattari, Félix. 1984. Molecular Revolution. Psychiatry and Politics. Tłum. R. Sheed. London: Penguin.

Guattari, Félix. 2011. „Schizo Chaosmosis”. Tłum. A. Goffey. W The Guattari Effect. Red. E. Alliez, A. Goffey. New York: Continuum. 
Adrian Mrówka - doktor nauk humanistycznych, nauczyciel języka polskiego, absolwent Uniwersytetu Śląskiego. Ukończył gender studies na Uniwersytecie Jagiellońskim. Rozprawę doktorską poświęcił kategorii podmiotowości w powieściach Stanisława Przybyszewskiego. Jego teksty były publikowane m.in. w Pamiętniku Literackim, Czasie Kultury, monografii Praybyszewski. Re-wizje i filiacje oraz tomach zbiorowych.

\section{DANE ADRESOWE:}

IV Liceum Ogólnokształcące

z Oddziałami Dwujęzycznymi

im. Stanisława Staszica,

pl. Waldemara Zillingera 1,

41-206 Sosnowiec

EMAIL: adr.mr@poczta.fm

CYTOWANIE: Adrian Mrówka. 2017. Felix Guattari, krytyka psychoanalizy i przypadek La Borde. Praktyka Teoretyczna 3(25): 331-341.

DOI: $10.14746 /$ prt.2017.3.15

\section{AUTHOR: Adrian Mrówka}

TITLE: Félix Guattari, Critics of Psychoanalysis and the Case of La Borde

ABSTRACT: The article explores basic theoretical approaches of Félix Guattari, who was associated with La Borde clinic where the innovative methods of institutional therapy were created. Criticizing Freud and Lacan's psychoanalysis, Guattari established non-traditional tools for treating individual and collective identities, as well as alternative means of perception for subjectivity production and group phantasm. At La Borde, Guattari, along with collaborators such as Frantz Fanon, developed the schizoanalytical method based on transversal relations and machinic unconsciousness, terms strictly related to the theoretical and philosophical assumptions of Anti-Oedipus.

KEYWORDS: Félix Guattari, La Borde, critics of psychoanalysis, subjectivity, schizoanalysis. 